\title{
Pengaruh Ukuran Butir, Fraksi Volume dan Penambahan Aseton terhadap Kekuatan Flexural Komposit Papan Partikel Serbuk Gergaji Kayu Sengon-Matrik Polyester
}

(The Effect of Grain Size, Volume Fraction and Addition of Acetone on Flexural Strength of Composite Board Sengon Wood Sawdust Particles-Polyester Matrix)

\author{
Muhammad Budi Nur Rahman ${ }^{\mathrm{a}}$, Sudarisman ${ }^{\mathrm{b}}$, Eko Nugroho ${ }^{\mathrm{c}}$ \\ ${ }^{a, b}$ Mechanical Engineering Department, Universitas Muhammadiyah Yogyakarta \\ Jl. Brawijaya, Tamantirto, Kasihan, Bantul, Yogyakarta, Indonesia 55183 \\ Telephone/fax (0274) 387656/ (0274) 387646 \\ e-mail: budinurrahman@umy.ac.id ${ }^{\text {a }}$ \\ 'Mechanical Engineering Department Universitas Muhammadiyah Metro \\ JI. Ki Hajar Dewantara No 114 Metro Timur, Kota Metro, Lampung, 34381 \\ Telephone/fax (0725) 42445 \\ e-mail: exonugros@yahoo.co.id
}

\section{Abstrak}

Papan partikel dapat digunakan sebagai bahan konstruksi pengganti kayu. Pengaruh ukuran partikel, fraksi volume, dan penambahan aseton pada matrik polyester perlu diketahui kekuatan, regangan, dan modulus/ sifat flexural (bending), serta moda patahannya. Spesimen dibuat dengan cetak tekan dari partikel kayu sengon sebagai penguat dan polyester sebagai matrik. Partikel yang digunakan dengan ukuran mesh 10 dan 20, variasi fraksi volume partikel $30,32.5,35,37.5$, dan $40 \%$ dengan matrik campuran polyester-aseton dengan variasi penambahan aseton $0,10,20$, dan $30 \mathrm{ml}$. Pengujian flexural menggunakan standar ASTM D 1037-99 dan analisa patahan dengan foto makro serta foto mikro untuk analisa struktur partikel komposit. Semakin kecil partikel yang digunakan, dapat meningkatkan sifat flexural karena luas rekatan antara partikel dan matrik semakin besar. Penambahan fraksi volume partikel mesh 20 meningkatkan sifat flexural sampai fraksi volume $37,5 \%$ namun pada fraksi volume $40 \%$ sifat flexural turun. Peningkatan fraksi volume partikel mesh 10 menurunkan sifat flexural papan partikel. Penambahan aseton menurunkan sifat flexural karena matrik semakin encer sehingga daya rekat polyester semakin berkurang. Patahan komposit papan partikel kayu sengon yaitu patah tunggal yang terjadi pada semua specimen.

Kata kunci: serbuk kayu sengon, polyester, ukuran butir, fraksi volume, aseton, kekuatan flexural

\begin{abstract}
Particle boards commonly used as wood replacement construction materials. The investigation of the influence of particle size, volume fraction and addition of acetone on the polyester matrix on their flexural properties and failure modes has been carried out. Specimens were fabricated by cold press from sengon wood particles as a reinforcement and the polyester as a matrix. The particles with mesh sizes of 10 and 20 were used, The composite boards were fabricated with particle volume fraction of $30,32.5,35,37.5$, and $40 \%$. Polyester as a matrix was prepared by adding acceton (0, 10, 20, $30 \mathrm{ml}$ ) into polyester . The flexural properties was examined in accordance to ASTM D 1037-99 standard. The microstructure and failure of mode of the the composite were determined by image analysis. The result show that the smaller particles increase flexural properties because the area of bond between particles and matrix is largerr. The addition of the volume fraction of 20 mesh particles increased the flexural properties to a volume fraction of $37.5 \%$ but at a volume
\end{abstract}


fraction of $40 \%$ the flexural properties decreased. Increasing the volume fraction of 10 mesh particles decreases the flexural properties of the particle board. The addition of acetone decreases flexural properties because the matrix is more thiner so that the adhesive power of polyester decreases. Single fracture mode was occurred in all specimens being examined.

Keywords: sengon wood powder, polyester, grain size, volume fraction, acetone, flexural strength

\section{Pendahuluan}

Dunia konstruksi banyak menggunakan material komposit dengan filler serat alam untuk memenuhi keinginan konsumen menggunakan komponen dengan material yang lebih kuat dan ringan, tetapi tetap memiliki estetika yang baik. Produsen mengembangkan teknologi untuk membuat komponen dengan material pengganti yang memiliki kelebihan dibandingkan logam dan memperbaiki kekurangan dalam segi kualitas. Natural Composite (NACO) berpeluang menggeser penggunaan komposit sintetis bahkan material logam dalam dunia teknik karena termasuk material ramah lingkungan. Indonesia yang kaya sumber daya alam dapat memproduksi NACO dengan penguat serat alam untuk diaplikasikan pada berbagai produk. Papan partikel dapat menggunakan limbah kayu atau bahan lainnya. Bahan limbah kayu dapat diperoleh dari industri penggergajian, salah satunya serbuk gergaji kayu sengon yang banyak ditemukan di Kabupaten Wonosobo, Jawa Tengah. Hasil hutan non-HPH Kabupaten Wonosobo berupa kayu gergajian mengalami peningkatan, rata-rata pertumbuhannya 27,36\% pada tahun 2009 peningkatan menjadi 106,8 juta $\mathrm{m}^{3}$. Limbah industri kayu sebesar 50,8\% bahan baku, terdiri dari 25,9\% sebetan, 14,3\% potongan kayu dan $10,6 \%$ serbuk gergaji. Kebutuhan kayu untuk konstruksi terus meningkat, tetapi ketersediaannya semakin sedikit sehingga diperlukan bahan pengganti seperti pengembangan papan partikel komposit atau baja ringan.

Peningkatan fraksi volume bahan penguat dapat meningkatkan kekuatan flexural material komposit. Kekuatan flexural komposit serat randu matrik polyester BQTN 157 disusun acak dengan fraksi volume 10\%, 20\%, dan 30\% berturut-turut 8,65 MPa, 11,06 $\mathrm{MPa}$, dan 12,16 MPa. Standar pengujian yang digunakan adalah ASTM D790 tipe AMU-5DE [6]. Demikian juga, pada komposit serat daun pisang matrik polyester dengan panjang serat $5 \mathrm{~cm}$ lebih tinggi daripada panjang serat $2 \mathrm{~cm}$. Kekuatan flexural terbesar pada Vf $40 \%$ sebesar 83,08 MPa sedangkan pada Vf 20\% sebesar 34,53 MPa dengan adanya retak pada pengamatan makro hasil patahan specimen [7]. Komposit serat nanas-nanasan (Bromeliaceae) kontinu searah matrik polyester pada Vf $40 \%$ sebesar $152,15 \mathrm{MPa}$ sedangkan Vf 20\% sebesar 144,48 MPa. Peningkatan lama waktu alkali serat selama 6 jam menghasilkan kekuatan flexural tertinggi sebesar 218,06 MPa dan pada perlakuan 8 jam sebesar 188,20 MPa [8]. Namun, pada komposit serat rami matrik polyester, peningkatan perlakuan alkali akan menurunkan kekuatan flexural. Komposit serat rami tanpa perlakuan alkali memiliki kekuatan flexural sebesar 70,39 MPa, sedangkan pada perlakuan alkali 6 jam sebesar 51,70 MPa [9]. Berbeda dengan penelitian lainnya, kekuatan flexural komposit serat sabut kelapa semakin turun dengan peningkatan fraksi volume meskipun regangan dan modulusnya sedikit meningkat. Kekuatan flexural pada Vf $40 \%$ sebesar 29,77 MPa dengan modulus 1,65 GPa dari kekuatan flexural polyester 77,93 MPa [10].

Komposit hybrid sandwich dengan Vf $30 \%$ terdiri dari $810 \mathrm{~g} / \mathrm{m}^{2}$ serat kenaf anyam dan $300 \mathrm{~g} / \mathrm{m}^{2}$ serat $E$-glass acak menggunakan matrik polyester dengan ketebalan core kayu sengon laut $10 \mathrm{~mm}$ arah serat kayu horizontal dan vertikal. kekuatan flexural komposit sandwich hybrid dengan core vertical sebesar 97,5 MPa meningkat $270 \%$ menjadi sebesar 263,28 MPa pada komposit sandwich hybrid dengan core horizontal. Kekuatan impak komposit sandwich dengan core arah serat kayu vertical $0.0604 \mathrm{~J} / \mathrm{mm}^{2}$, lebih besar $4,4 \%$ dari pada komposit sandwich core arah serat kayu horizontal $0,0578 \mathrm{~J} / \mathrm{mm}^{2}$ [2].

Semakin tebal core dapat meningkatkan momen bending dan kekuatan flexural hybrid sandwich berdasarkan standar pengujian ASTM C393. Komposit sandwich dengan fraksi volume skin 30\% dari serat kenaf dan serat gelas matrik polyester dan core kayu sengon laut dipotong melintang dengan ketebalan 5, 10, 15, dan $20 \mathrm{~mm}$. Kekuatan bending 
komposit hybrid sandwich akan menurunkan apabila serat kenaf mengalami perlakuan alkali selama 2 jam. Patahan diawali dari kegagalan skin yang mengalami tegangan tarik selanjutnya kegagalan geser pada core kayu sengon diakhiri skin yang menerima tekan dan kegagalan delaminasi antara skin dengan core komposit. [3].

Komposit sandwich hybrid diperkuat oleh tenunan kenaf dan serat kaca acak menggunakan core kayu sengon laut dengan matrik polyester tak jenuh 268 BQTN. Core dibuat dengan memotong kayu sengon arah melintang dan perlakuan larutan boraks $5 \%$. Ada dua jenis komposit sandwich, yaitu GFRP dan komposit sandwich hybrid, dibuat dengan metode hand lay-up. Hasil pengujian three point bending menghasilkan kekuatan bending komposit sandwich hibrida (97,50 MPa) adalah 0,93\% lebih tinggi dari GRFP sandwich komposit $(87,89 \mathrm{MPa})$. Begitu pula dengan kekuatan sandwich komposit lebih tinggi dari kekuatan komponennya juga. Pengamatan kegagalan permukaan menunjukkan kerusakan diawali dari tegangan skin dan diikuti kerusakan pada intinya. [4]

Semakin banyak serat aren akan meningkatkan sifat fisik dan mekanik papan. Substitusi potongan karet ban tidak banyak memberikan kontribusi terhadap karakteristik papan (nilai cenderung tetap bahkan ada yang turun). Papan partikel serat aren menghasilkan kadar air $8,567 \%$, massa jenis papan $0,581 \mathrm{~g} / \mathrm{cm}^{3}$ dengan kekuatan lentur $82,120 \mathrm{~kg} / \mathrm{cm}^{2}$ masuk dalam kategori kualitas sedang. Papan komposit memiliki kadar air $9,953 \%$, massa jenis $0,864 \mathrm{~g} / \mathrm{cm}^{3}$ dan nilai kekuatan lentur $478,518 \mathrm{~kg} / \mathrm{cm}^{2}$ dikatagorikan dalam kualitas sedang mendekati tinggi. Lapisan finir pada kedua sisi luar papan partikel menjadi papan komposit sehingga dapat meningkatkan kualitas papan partikel. Papan partikel yang paling optimal dengan bahan perekat UF jenis UA 147 (15\%) dengan komposisi serat aren $50 \%$ dan serbuk gergaji (partikel) $50 \%$ [5].

Kini, dunia perkapalan telah menggunakan komposit limbah alami sebagai material pendukung komponennya. Pengujian lentur skin komposit sandwich serat daun nanas sebesar 32,834 MPa dan kayu sengon laut sebagai core sebesar 43,260 MPa setelah disusun menjadi komposit sandwich memiliki kekuatan lentur 27,726 MPa. Hal itu masih jauh dari standar konstruksi yang dipersyaratkan Biro Klasifikasi Indonesia sebesar 150 $\mathrm{MPa}$. Demikian juga, ketangguhan impak komposit sandwich sebesar $0,465 \mathrm{~J} / \mathrm{mm}^{2}$ meskipun ketangguhan impak skin sebesar $0,655 \mathrm{~J} / \mathrm{mm}^{2}$ dan core kayu sengon laut sebesar $0,658 \mathrm{~J} / \mathrm{mm}^{2}$ belum bisa memenuhi standar JIS. Penggunaan komposit sandwich dapat digunakan untuk komponen lain, seperti meja, jendela, pintu, lemari, dan lain-lain. [1]

Papan partikel dari kayu kelapa sawit (KKS) dengan matrik polystyrene (PS) benzoyl peroxide dengan katalis maleated dan xilena sebagai pelarut menunjukkan penambahan bahan berekat dapat meningkatkan kekuatan tarik dan kekuatan lentur. Papan partikel KKSPS dapat digunakan mulai dari komposisi KKS-PS 60:40 dengan kekuatan tarik optimum $55,15 \mathrm{~kg} / \mathrm{cm}^{2}$ dan kekuatan bending optimum $92,27 \mathrm{~kg} / \mathrm{cm}^{2}$ serta memenuhi standar SNI 032105-1996 [11].

Partikel yang semakin kecil memiliki kekuatan dan modulus flexural yang semakin tinggi, tetapi hal tersebut dapat menurunkan regangannya. Peningkatan fraksi volume akan menurunkan kekuatan flexture, sedangkan modulus flexturenya sedikit meningkat. Kekuatan dan modulus flexural papan partikel dengan mesh 16 sebesar 47,89 MPa dan 1,61 GPa, sedangkan dengan mesh 11 sebesar 32,49 MPa dan 1,62 GPa pada Vf $30 \%$. Penambahan Vf menjadi $40 \%$ dengan mesh 16 kekuatan flexural turun menjadi $37,57 \mathrm{MPa}$ dan $30,37 \mathrm{MPa}$ dengan mesh 11, sedangkan modulusnya naik menjadi 2,618 GPa pada mesh 16 dan 2,209 GPa pada mesh 11. Moda patahan papan partikel adalah patah getas tunggal, berbeda dengan epoksi yang mengalami pecah menjadi potongan [12].

Penelitian sebelumnya kayu sengon digunakan untuk core komposit sandwich, sedangkan serbuk gergajinya belum dimanfaatkan secara optimal. Serbuk kayu sengon dapat dicetak menjadi papan partikel yang dapat langsung dimanfaatkan maupun menjadi core komposit sandwich. Tujuan penelitian ini untuk mengetahui pengaruh fraksi volume partikel dan penambahan aseton pada matrik terhadap sifat flexural papan partikel (serbuk) gergaji sengon laut sehingga bermanfaat dalam bidang industri atau nonindustri.

\section{Metode}

\subsection{Persiapan Bahan}

Penelitian ini menggunakan bahan antara lain: 
1. Serbuk gergaji kayu sengon digunakan sebagai filler dalam pembuatan papan partikel diperoleh dari daerah Wonosobo. Sebelum dicetak, serbuk kayu mendapatkan perlakuan sebagai berikut:

a. Serbuk gergaji kayu yang masih dalam kondisi bagus dijemur sampai kering.

b. Serbuk diayak dengan mesh 10 dilanjutkan dengan mesh 20. Serbuk yang lolos mesh 20 (serbuk kecil) yang tidak lolos mesh 20 (serbuk besar).

c. Selanjutnya, serbuk dikeringkan dalam panas oven pada suhu $60^{\circ} \mathrm{C}$ selama 60 menit.

d. Penimbangan untuk membuat variasi fraksi volume partikel penguat komposit sebesar $30 \%, 32,5 \%, 35 \%, 37,5 \%$, dan $40 \%$.

2. Resin Polyester $268 \AA$ BTQN series digunakan sebagai matrik untuk mengikat serbuk gergaji kayu sengon.

3. Katalis, sebagai bahan tambahan unntuk mempercepat proses pengeringan matrik. Di mana katalis yang digunakan hanya $0,1 \%$ dari jumlah matrik.

4. Aseton, digunakan untuk mengencerkan resin polyester dengan variasi campuran 10 $\mathrm{ml}, 20 \mathrm{ml}, 30 \mathrm{ml}$

\subsection{Pencetakan Spesimen}

Pencetakan komposit dilakukan pada pelat baja dengan ukuran lebar $300 \mathrm{~mm}$ dan panjang $400 \mathrm{~mm}$ dengan ukuran cetakan $200 \mathrm{~mm} \times 260 \mathrm{~mm} \times 6 \mathrm{~mm}$ yang dibatasi dengan kaca. Pencetakan komposit dilakukan dengan metode cetak tekan (press mould). Penelitian dilakukan dengan 3 (tiga) variasi yaitu:

1. Butiran partikel sengon laut, dipisahkan dengan ayakan mesh 10 (serbuk besar) dan mesh 20 (serbuk kecil).

2. Fraksi volume partikel penguat dengan yaitu $30 \%, 32,5 \%, 35 \%, 37,5 \%$, dan $40 \%$.

3. Cairan pengencer aseton yang ditambahkan pada matrik polyester dan katalis MEKPO sebanyak $10 \mathrm{~mm}, 20 \mathrm{ml}, 30 \mathrm{ml}$.

Setelah semua bahan dicampurkan sesuai dengan perhitungan yang telah dilakukan, bahan dituangkan dalam cetakan kemudian di-rol dan ditutup pelat baja, kemudian ditekan dengan dongkrak hidrolik. Pelepasan cetakan dilakukan setelah papan partikel terbentuk selama 6 jam penekanan.

\subsection{Pengujian Flexural (Bending)}

Pengujian flexural dilakukan untuk mengetahui ketahanan material terhadap beban lentur, regangan, dan modulus elastisitas bahan serta memastikan sifat-sifat dan kekuatan bahan tersebut. Pembebanan flexural mengakibatkan bagian bawah spesimen menerima tegangan tarik, sedangkan bagian atas akan mengalami tegangan tekan. [13]. Pengujian flexural dilakukan dengan cara memberikan beban lentur secara perlahan-lahan sampai spesimen mengalami fracture. Pengujian flexural dapat digunakan untuk menguji bahan getas atau bahan liat dengan mengetahui adanya cacat dan retakan permukaan material serta cara terbaik untuk menentukan kekuatan bending dan kegetasan material.

Dalam penelitian ini, pengujian flexural menggunakan metode three point bending sesuai standar ASTM D1037-99 dengan dimensi specimen seperti Gambar 2.1.
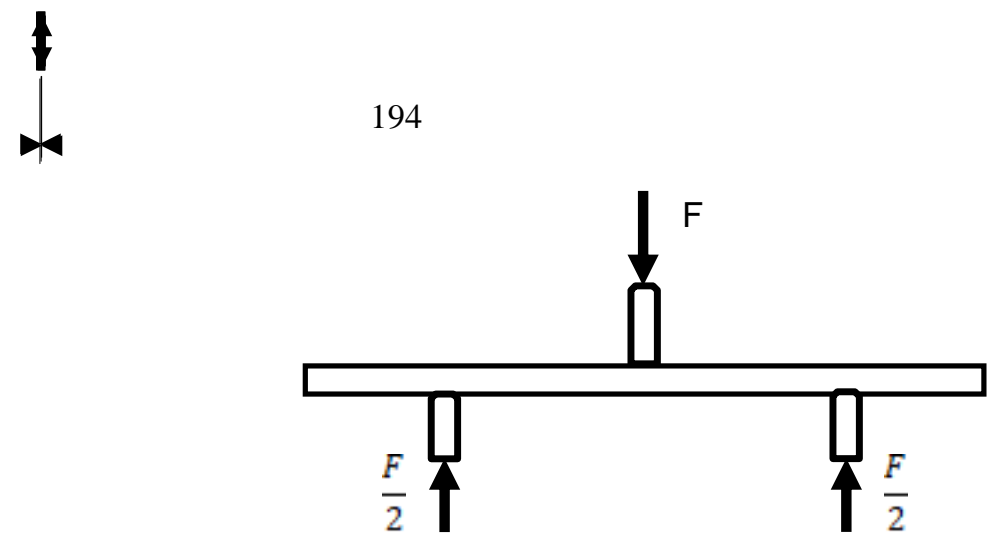

Gambar 2.1. Dimensi balok serta metode pengujian flexural 
Hasil pengujian tidak langsung diperoleh sifat-sifat flexural. Berdasarkan standar ASTM D 1037-99, sifat material komposit dihitung dengan persamaan:

1. Kekuatan flexural

$$
\sigma_{b}=\frac{3 P L}{2 b d^{2}}
$$

2. Regangan flexural

$$
\varepsilon_{b}=\frac{6 D \cdot d}{L^{2}}
$$

3. Modulus elastisitas

$$
E=\frac{3 L^{a} \cdot m}{4 b \cdot d^{3}}
$$

Dengan: $\sigma_{\mathrm{b}}=$ kekuatan flexural $(\mathrm{MPa}), P=$ beban $(\mathrm{N}), L=$ panjang span $(\mathrm{mm}), b=$ lebar $(\mathrm{mm}), d=$ tebal $(\mathrm{mm}), \varepsilon_{b}=$ regangan flexural $(\mathrm{mm} / \mathrm{mm}), D=$ defleksi $(\mathrm{mm}), E=$ modulus elastisitas $(\mathrm{MPa}), \mathrm{m}=$ slope tengent

\section{Hasil dan Pembahasan}

3.1 Pengaruh Fraksi Volume Terhadap Sifat Flexural

Hasil pengujian variasi fraksi volume partikel dan perhitungan nilai kekuatan, regangan, dan modulus flexural menggunakan persamaan (1), (2), dan (3) dapat dilihat pada Gambar 3.1.

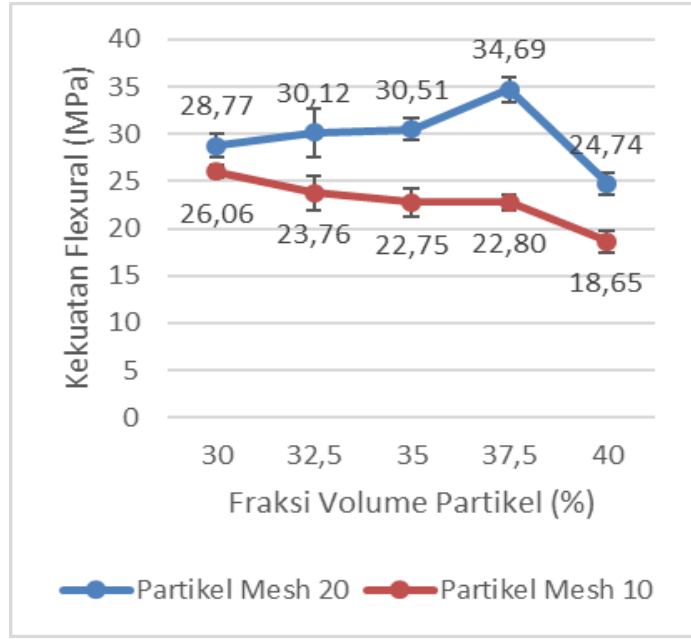

(a) Kekuatan Flexural Papan Partikel

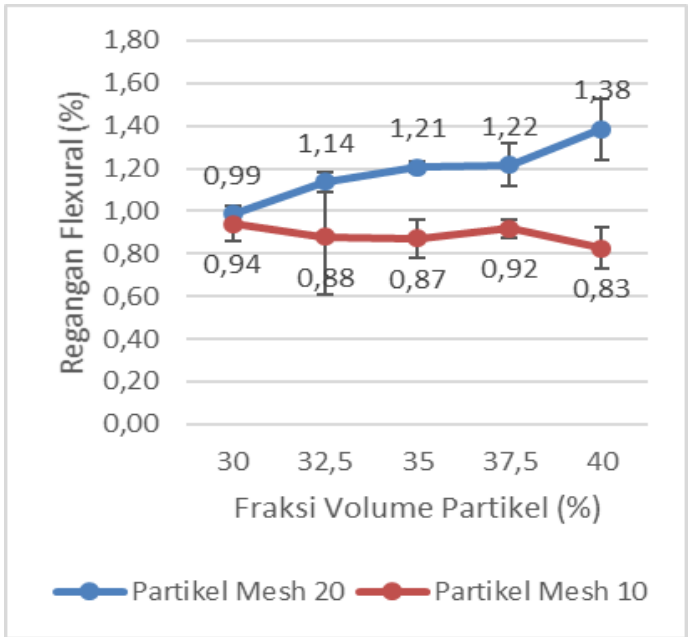

(b) Regangan Flexural Papan Partikel

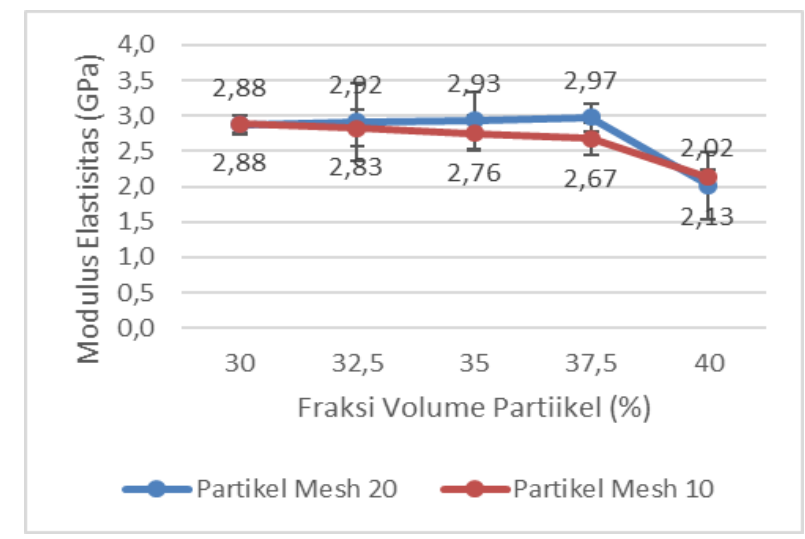

(c) Modulus Elastisitas Flexural Papan Partikel

Gambar 3.1. Grafik Pengaruh Fraksi Volume Partikel terhadap Sifat Flexural Papan Partikel Serbuk Gergaji Kayu Sengon 
Gambar 3.1.a menunjukkan bahwa partikel kecil (mesh 20) memiliki nilai kekuatan flexural yang semakin meningkat dengan penambahan fraksi volume sampai $\mathrm{Vf} 37,5 \%$ mencapai maksimum sebesar 34,69 MPa. Namun, pada Vf $40 \%$ sebesar $24,74 \mathrm{MPa}$ kekuatan flexural lebih rendah dari pada $\mathrm{Vf} 30 \%$ sebesar $28,77 \mathrm{MPa}$. Kekuatan flexural papan partikel besar (mesh 10) menunjukkan penurunan dengan bertambahnya fraksi volume, pada Vf $30 \%$ sebesar $26,06 \mathrm{MPa}$ menjadi $18,65 \mathrm{MPa}$ pada $\mathrm{Vf} 40 \%$. Hal ini disebabkan pada butiran partikel besar dihasilkan oleh kualitas pembasahan matrik pada filler yang tidak sama. Pembasahan yang tidak sempurna menyebabkan integritas struktur filler cenderung lemah sehingga distribusi dan transfer beban menjadi rendah. Semakin kecil ukuran partikel menyebabkan luas permukaan ikatan matrik dengan filler menjadi semakin besar sehingga beban yang mampu diterima akan semakin besar. Namun, jika fraksi volume terlalu besar, matrik tak mampu membasahi seluruh permukaan filler atau terdapat void pada permukaan partikel atau pada matrik. Akibatnya, kemampuan menahan beban menjadi rendah seperti terlihat pada Gambar 3.2.
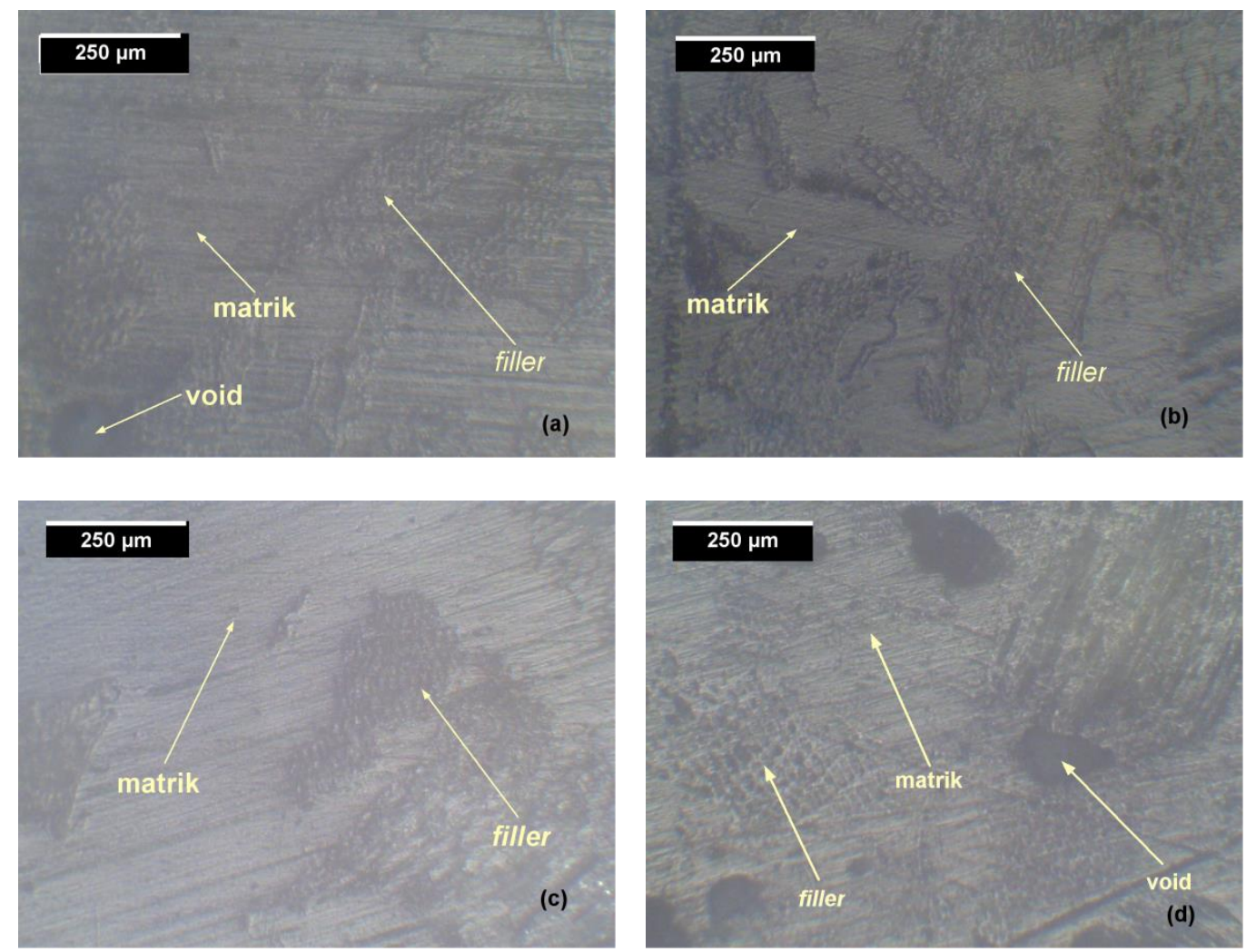

Gambar 3.2. Foto mikro komposit papan partikel variasi ukuran butir mesh 20

(a) $V_{f}=30 \%$, (b) $V_{f}=35 \%$, (c) $V_{f}=37,5 \%$, (d) $V_{f}=40 \%$

Gambar 3.2.b menunjukkan papan komposit dengan partikel kecil mengalami peningkatan regangan dengan penambahan fraksi volume filler. Regangan papan partikel dengan filler besar cenderung semakin turun dengan penambahan fraksi volume. Nilai regangan dilihat dari besarnya defleksi saat pengujian, semakin besar defleksi maka harga regangan akan semakin besar. Nilai regangan komposit papan partikel kecil pada Vf $30 \%$ sebesar $0,99 \%$ meningkat menjadi $1,38 \%$ untuk Vf $40 \%$, sedangkan pada partikel besar dari $0,94 \%$ pada Vf $30 \%$ turun menjadi $0,83 \%$ pada Vf $40 \%$. Semakin besar regangan menunjukkan material semakin lentur. Sebaliknya, jika regangannya rendah menunjukkan material semakin getas.

Penambahan fraksi volume tidak banyak berpengaruh terhadap peningkatan modulus elastisitas papan partikel seperti terlihat pada Gambar 3.2.c. Nilai modulus elastisitas hampir sama yaitu sebesar 2,8 GPa sampai Vf $37,5 \%$ dan pada Vf $40 \%$ modulus elastisitas turun menjadi $2 \mathrm{GPa}$. Modulus elastisitas tidak lepas dari kekuatan flexural dan regangan 
flexuralnya. Partikel serbuk gergaji sengon mengandung sifat pith (gabus) yang mengandung sel parenkim. Sel ini tidak memberikan sifat kekuatan yang menyebabkan turunnya kekuatan papan partikel komposit.

\subsection{Pengaruh Aseton pada Matrik Polyester terhadap Sifat Flexural}

Berdasarkan hasil pengujian papan partikel pada variasi penambahan aseton pada matrik polyester dan perhitungan menggunakan persamaan (1), (2), dan (3), diperoleh nilai kekuatan, regangan, dan modulus flexural ditampilkan pada Gambar 3.3.

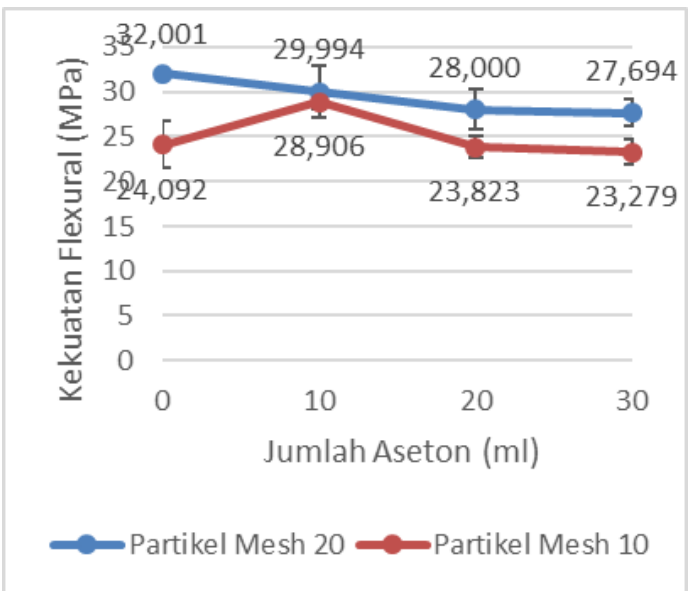

(a) Kekuatan Flexural Papan Partikel

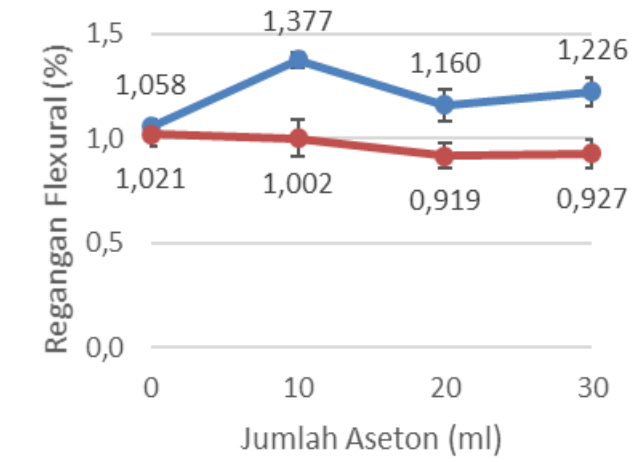

-Partikel Mesh $20 \longrightarrow$ Partikel Mesh 10

(b) Regangan Flexural Papan Partikel

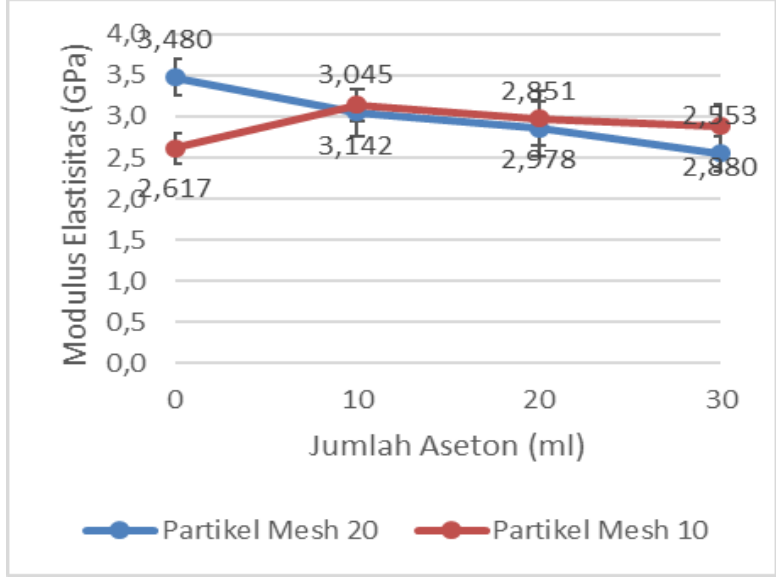

(c) Modulus Elastisitas Flexural Papan Partikel

Gambar 3.3. Grafik Pengaruh Penambahan Aseton Pada Matrik Polyester Terhadap Sifat Flexural Papan Partikel Serbuk Gergaji Kayu Sengon

Pemberian cairan aseton pada matrik tidak sesuai dengan harapan awal. Cairan aseton dimaksudkan untuk mengencerkan matrik sehingga meningkatkan pembasahan partikel sehingga lebih mudah dalam pencampuran dan menigkatkan ikatan antarpartikel. Namun, dari hasil pengujian diperoleh penurunan kekuatan flexural dan modulus elastisitasnya dengan regangan yang relatif tidak banyak berubah. Papan partikel tanpa penambahan aseton memiliki kekuatan flexural 32,001 MPa dan turun sampai 27,694 MPa dengan penambahan aseton $30 \mathrm{ml}$. Demikian juga, modulus elastisitas juga mengalami penurunan dari 3,480 $\mathrm{GPa}$ menjadi 2,880 GPa.

\subsection{Moda Patahan Pengujian Flexural}

Gambar 3.4 menunjukkan penampang patah hasil pengujian flexural sehingga tampak semua specimen mengalami patah tunggal. Hal ini menunjukkan kemampuan komposit partikel kekuatannya sangat rendah untuk menerima beban lentur. 


\section{$\overline{\Pi \Pi}_{\text {Teknik }}$}

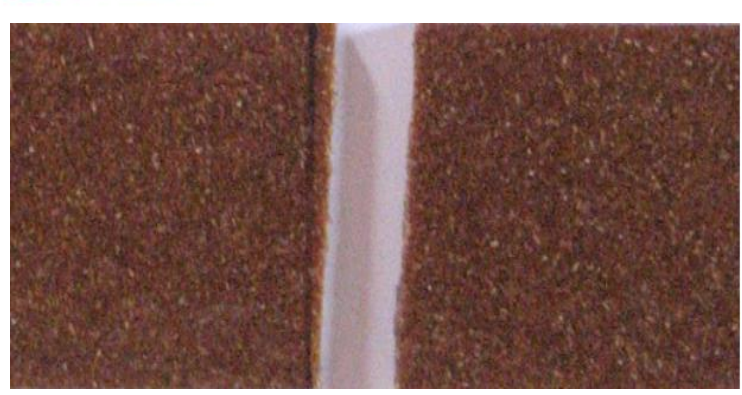

(a) $\mathrm{Vf} 37,5 \%$

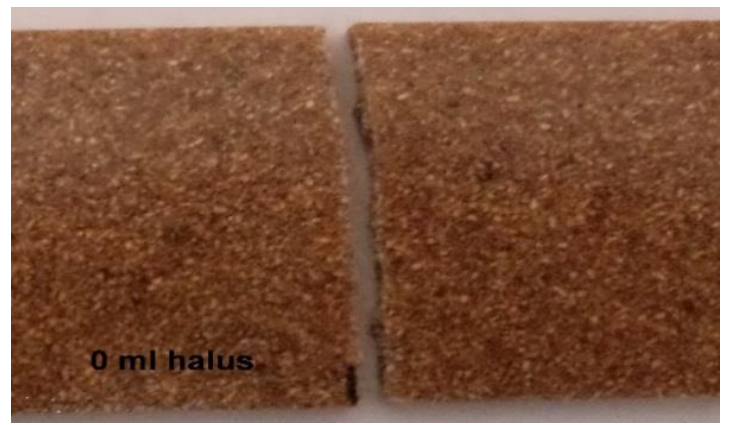

(c) Aseton $0 \mathrm{ml}$

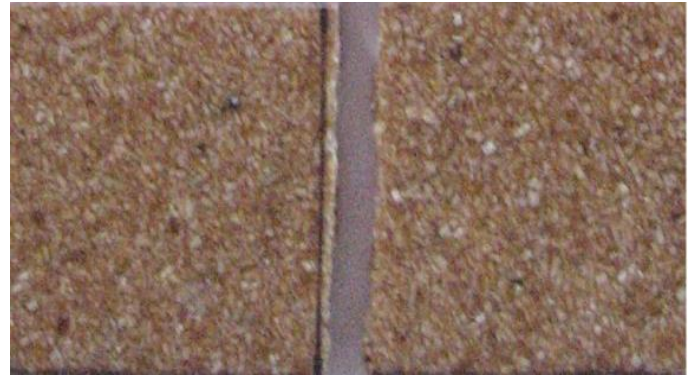

(b) Vf $40 \%$

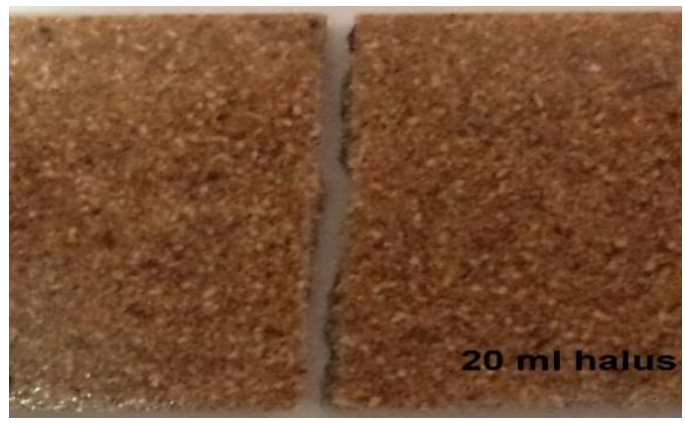

(d) Aseton $20 \mathrm{ml}$

Gambar 3.4. Penampang patahan pengujian flexural

\section{KESIMPULAN}

Kesimpulan hasil penelitian ini adalah sebagai berikut:

1) Semakin kecil ukuran partikel yang digunakan dapat meningkatkan kekuatan, regangan, dan modulus flexural karena rekatan antara partikel dengan matrik semakin luas. Sifat flexural pada partikel mesh 20 dengan fraksi volume $30 \%$ berturut-turut sebesar $28,888 \mathrm{MPa}, 0,98 \%$, dan 2,878 GPa dari 26,058 $\mathrm{MPa}, 0,94 \%$, dan 2,883 $\mathrm{GPa}$ pada partikel mesh 10.

2) Penambahan fraksi volume partikel kayu sengon pada mesh 20 meningkatkan sifat flexural maksimum sampai fraksi volume $37,5 \%$ berturut-turut $34,694 \mathrm{MPa}, 1,22 \%$, dan $3,201 \mathrm{GPa}$. Namun, sifat flexural turun pada fraksi volume $40 \%$ sebesar $24,737 \mathrm{MPa}$, $1,38 \%$, dan $1,913 \mathrm{GPa}$. Penambahan fraksi volume partikel kayu sengon pada mesh 10, menurunkan sifat flexural papan partikel pada fraksi volume $40 \%$ berturut-turut $19,048 \mathrm{MPa}, 0,82 \%$, dan 2,499 GPa.

3) Penambahan aseton menurunkan nilai kekuatan dan modulus elastisitas flexural karena matrik semakin encer sehingga daya rekat polyester semakin berkurang, tetapi regangan flexural sedikit meningkat. Penambahan aseton sebanyak $30 \mathrm{ml}$ menghasilkan sifat flexural sebesar 27,69 MPa, 1,27\%, dan 2,553 GPa.

4) Penampang patahan komposit papan partikel kayu sengon dengan matrik polyester berupa patah tunggal terjadi pada semua specimen.

\section{Daftar Pustaka}

[1] Hidayat, A., Yudo, H., Manik, P, Kekuatan Bending Komposit Hibrid Sandwich Kombinasi Serat Kenaf Dan Serat Gelas Dengan Core Kayu Sengon Laut, Jurnal Teknik Perkapalan - Vol.4, No. 1 Januari 2016, 265-273

[2] Febrianto, B., Diharjo, K., Kekuatan Bending Dan Impak Komposit Hibrid Sandwich Kombinasi Serat Karung Goni Dan Serat Gelas Polyester Dengan Core Kayu Sengon Laut, Skripsi Surakarta, Undergraduate UNS, 2004.

[3] Hariyanto, A., Peningkatan Ketahanan Bending Komposit Hibrid Sandwich Serat Kenaf Dan Serat Gelas Bermatrik Polyester Dengan Core Kayu Sengon Laut, MEDIA MESIN, 2007, Vol.8 No.1, Januari 2007, 1 - 9 
[4] Diharjo, K., Kekuatan Bending Komposit Hibrid Sandwich Kombinasi Serat Kenaf Dan Serat Gelas Dengan Core Kayu Sengon Laut, Jurnal Gema Teknik, 2007, Vol X, No. 1, Januari 2007, 11-15.

[5] Rachman, A., Pengembangan Teknologi Papan Partikel Dengan Memanfaatkan Limbah Pohon Aren (Kayu dan Serat) dan Limbah Karet Ban Bekas Sebagai Alternatif Menciptakan Produk Papan Komposit Unggulan, Desember, 2009.

[6] Hendarto., Uji Karakteristik Sifat Fisisdan Mekanis Komposit serat Acak Cieba Pentandra (Kapuk Randu) Dengan Fraksi Berat Serat 10\%, 20\%, dan 30\%. Skripsi Undergraduate UMS, Surakarta, 2011.

[7] Boimau, K., Pengaruh Fraksi Volume dan Panjang Serat Terhadap Sifat Bending Komposit Polyester Yang Diperkuat Serat Batang Pisang, Seminar Nasional Teknik Mesin IX, Palembang, 2010.

[8] Rahman, M.B.N., Suwanda, T., dan Diharjo, K., Studi Optimasi Peningkatan Kekuatan Bending Komposit Berpenguat Serat NanasNanasan (Bromeliaceae) Kontinu Searah, Jurnal Ilmiah Semesta Teknika, Vol. 11 No. 2 (November 2008): 207-217

[9] Suwanda, T., dan Rahman, M.B.N., Pengaruh Perlakuan Alkali terhadap Kekuatan Bending Komposit Berpenguat Serat Rami dengan Matrik Polyester, Jurnal Semesta Teknika, Vol. 13, No. 2, November 2010, 165-170

[10] Assidiq, M.J., Pengaruh Fraksi Volume Serat Terhadap Kekuatan Tarik dan Bending Pada Material Komposit Serat Serabut Kelapa Unidireksional / Epoksi, Skripsi Undergraduate UMY, Yogyakarta, 2011.

[11] Mawardi, I., Mutu Papan Partikel dari Kayu Kelapa Sawit Berbasis Pereket Polystyrene, JURNAL TEKNIK MESIN, 2009, Vol. 11, No. 2, Oktober 2009: 91-96

[12] Sudarisman, Rahman, M.B.N., Darmawan, A., "Sifat-sifat Lentur Papan Partikel Komposit Kulit Kacang Tanah/Epoksi", The 7th University Research Colloquium (URECOL), Surakarta, 2018: 76-83.

[13] Schwartz, M.M., Composite Material Handbook, Mc Graw-Hill, Singapura. 1984. 